\title{
Design and production of maize beer
}

\begin{abstract}
Beer is an alcoholic beverage made by brewing and fermentation from cereals, usually malted barley and flavored with hops and the like for a slightly bitter taste. It is widely consumed throughout the world and global production during the last decade. In Africa, the alcoholic beverages such as liqueurs, wine and especially barley beer are much consumed both during moments of joy (festivals, weddings, success in examinations or competitions, winning football matches, etc.) and moments of sadness (funerals, job losses, poverty etc.). The sale of beer is a significant source of revenue for the owners of the maquis, restaurants etc. It is therefore a creative activity of jobs. According to many works such as "health for all", barley beer would have many health benefits if it is consumed in moderate amounts. Some of these interesting health benefits would include the following: anti-cancer properties, reduced risk of cardiovascular diseases, increased bone density, diabetes, prevention of anemia, hypertension, anti-aging properties, gallstones, prevention of dementia and coronary disease, aids digestive system, kidney stones and osteoporosis, stress buster, diuretic. But unfortunately, barley beer is imported. To lessen the import costs, we want to produce a local beer that may have the similar characteristics like beer barley beer from another cereal, maize. Unlike barley, maize grows very well in all tropical countries of Africa. Qualitatively, the chemical and biochemical components are almost the same as well as in both barley and maize. There are several types of strains of microorganisms used for the production of beer, such as lactic bacteria and yeast. But we have used a yeast strain: Saccharomyces cerevisiae which we can find easily and cheaply. The manufacturing processes of our maize beer essentially involve treatment of grains, malting or germination, mashing or extraction with water, filtration and fermentation. Germination process is halted at desired malt quality, green brown malt is converted to stable, storable product, colour and flavor are developed, enzymes are stabilized and preserved, and unwanted flavours are removed.
\end{abstract}

The objectives of mashing are solubilization and dissolution of grain components, break down of grain cell wall structure extraction and hydrolysis of starch, sugars, proteins and non-starch polysaccharides, fermentable sugar profile is established. During the fermentation, alcohol level is established, flavor profile of beer is established and carbonation level is established. At the end of fermentation, yeast flocculates and can be easily separated. Cold maturation temperatures will influence beer clarity. Using a systematic procedure to solve material balance problems, mass balances in all six steps in this production process were solved. The results shows that this process is more effective for maximize product yields due to the approximately equal of receipt and expenditure with high yield for each operation.

Keywords: brewing, fermentation, cereals, barley, beverages, liqueurs
Volume 6 Issue I - 2018

\section{Guillaume Ore,' Maxim Mironov,' Alexey Shootov ${ }^{2}$}

'Department of Technology for organic Synthesis, Institute of Chemical Engineering, Ural Federal University, Russia ${ }^{2}$ Beersfan Company, Russia

Correspondence: Guillaume Ore, Department of Technology for organic Synthesis, Institute of Chemical Engineering, Ural Federal University, 19, Mira Street, 620002 Yekaterinburg, Russia, Email oreguigui@hotmail.com

Received: August 30, 2016 | Published: January 25, 2018

\section{Introduction}

\section{Comparison of barley and maize}

Barley beer is a widely consumed alcoholic beverage throughout the world and global production figures have shown an increasing trend during the last decade. In Africa, the alcoholic beverages such as liqueurs, wine and especially barley beer are much consumed both during moments of joy (festivals, weddings, success in examinations or competitions, winning football matches etc.) and moments of sadness (funerals, job losses, poverty, etc.). The sale of beer is a significant source of revenue for the owners of the maquis, restaurants, etc. It is therefore a creative activity of jobs. But unfortunately, barley beer is imported. To lessen the import costs, we want to produce a local beer that may have the similar characteristics as beer barley beer from another cereal, maize. This can also allow us to diversify the raw material of beer in temperate countries in order to promote cooperation between Russia and African tropical countries for example. Unlike barley, maize grows very well in all tropical countries of Africa. The Table 1 below shows the comparative chemical composition of barley and maize. ${ }^{1-13}$

Qualitatively, the chemical and biochemical components are almost the same as well as in both barley and maize. Corn beer in the Andes has pre-Incan origins. There is archeological evidence that elite women were responsible for brewing in the Wari culture (600 to 1000 AD). In 1796 John Boston created a corn beer, the first fermented alcohol beverage made at Sydney, Australia. Traditionally, barley was the main grain used in brewing beer. However, many brewers use other grains along with barley. Most of the beer sold in the world is made with rice or corn making up a healthy portion of the grain bill. For just one Peruvian sol (around 30 cents), you can get drunk in Peru's Sacred Valley. Concealed amid the areas monstrous mountains, a series of domestic speakeasies serve an ancient Andean drink known as chicha de jora, a fermented corn beer dating back to the ancient Incan Empire. Still widely consumed in the Andean highlands, 
locals homebrew the concoction through a series of methodical steps involving the germination of jora (a type of yellow corn), a crop revered for its life-sustaining attributes.

\section{Health benefits of barley beer}

According to many research works related to health benefits of beer, such as "Bio-medicine" for example, barley beer would have many health benefits if it is consumed in moderate amounts. Some of these interesting health benefits would include the following:

\section{Anti-cancer properties}

Hops used in beer, through its flavonoid compound called Xanthohumol, would play a major role in the chemoprevention of cancer, including prostate cancer.

\section{Reduced risk of cardiovascular diseases}

Beer would contain vitamin B6, which would protect against heart diseases by preventing the build-up of a compound called homocysteine. Increased Bone Density: Moderate beer consumption would increase bone density, thereby preventing the risk of fractures and osteoporosis.

\section{Diabetes}

Moderate beer consumption would have a lower prevalence of type 2diabetes.

\section{Prevention of anemia}

Beer would be a good source of vitamin B12 and folic acid which would prevent anemia. Vitamin B12 is also essential for maintaining normal growth, good memory and concentration.

\section{Hypertension}

According to Biomedicine, regular beer drinkers would have lower blood pressure, compared to people that consume similar amounts of wine or other spirits.

\section{Anti-aging properties}

Beer would increase the potency and impact of vitamin E, which is a major antioxidant in the body. It would be an important part of the maintenance of healthy skin, while also slowing down the aging process.

\section{Gallstones}

Regular consumption of moderate amounts of beer would affect the cholesterol levels and decreases bile concentration, leading to a reduced risk of developing gallstones.

\section{Prevention of dementia and coronary disease}

Beer consumption also would boost the level of "good cholesterol" by $10-20 \%$, thus reducing the risk of dementia and cardiovascular diseases.

\section{Aids digestive system}

Beer would possess a number of digestive properties, which would include the stimulation of gastrin, gastric acid, cholecystokinin and pancreatic enzymes.

\section{Kidney sones and osteoporosis}

Potassium, sodium and magnesium would be present in and would be important in reducing risk of kidney stones. The silicon would be also present in beer and would be readily absorbed by the body, further explaining the protective effect of beer against osteoporosis.

\section{Stress buster}

Beer would reduce stress, and facilitates sleep. So would do other alcohols.

\section{Diuretic}

Beer would act as a diuretic and significantly would increase urination. This facilitates the increased removal of toxins and waste materials from the body.

\section{Maize beer production procedures}

The main source maize beer is starch and its production includes the following steps:

\section{Treatment of maize grains}

The aim of this stage is to have safety grains. Therefore, detoxification of grain before malting may not be practical unless further growth of the mold is also prevented. Physical, biological, chemical and biological methods are used for inhibiting mold growth in grain.

\section{Germination or malting}

Grain is soaked in water. Water is absorbed by the grain. There are hydration of grain embryo and stimulation of grain for start of germination. Activities of embryo are awakened, and enzymes will be distributed evenly throughout the kernel. Grain is placed in shallow vessels. Water is removed. Aleurone layer is stimulated to produce enzymes. Enzymes act to degrade cell wall structures. Enzymes are stimulated from the aleurone layer and there is hydrolysis of proteins, carbohydrates, hemicellulose and lipids in maize grain. The temperature of the malt is raised from 15 to $85^{\circ} \mathrm{C}$ in a controlled manner (temperature, airflow, time). Germination process is halted at desired malt quality, green brown malt is converted to stable, storable product, colour and flavor are developed, enzymes are stabilized and preserved and unwanted flavours are removed.

\section{Extraction with water or Mashing}

Milled grain is mixed with water at various temperatures, rest times, agitation. Temperatures are optimized for the malt enzymes: $50^{\circ} \mathrm{C}$ for proteolysis, $62^{\circ} \mathrm{C}$ for gelatinization/liquefaction, $72^{\circ} \mathrm{C}$ for saccharification and $78^{\circ} \mathrm{C}$ for mashing-off and malt enzyme inactivation. There are solubilization and dissolution of grain components, break down of grain cell wall structure extraction and hydrolysis of starch, sugars, proteins and non-starch polysaccharides, fermentable sugar profile is established. Wort (aqueous solution) is separated from the spent grains $\left(78^{\circ} \mathrm{C}\right)$. Grain bed is spared with hot water to extract as much extract as possible. Degree of clarity of wort is established; extract level of wort is established. Wort is boiled at $100^{\circ} \mathrm{C}$; hops are added during the boil. We have evaporation of water, coagulation of proteins, isomerization of hop bitter components, inactivation of enzymes, wort sterilization, evaporation of undesirable volatiles, formation of flavour compounds and colour development. 


\section{First filtration}

Insoluble material is separated from the wort solution. Coagulated proteins and insoluble hops material are removed.

\section{Fermentation}

Wort solution then cooled to yeast pitching temperature $\left(21-25^{\circ} \mathrm{C}\right)$. Temperature is reduced to allow for yeast addition, Yeast is added to sterile cooled wort (cold temperatures encourage precipitation of proteins and beer clarification). Wort components of sugars and proteins are utilized by yeast to form alcohol, $\mathrm{CO}_{2}$ and flavor components according to the following chemical reaction:

$$
\mathrm{C}_{6} \mathrm{H}_{12} \mathrm{O}_{6} \rightarrow 2 \mathrm{C}_{2} \mathrm{H}_{5} \mathrm{OH}+2 \mathrm{CO}_{2}
$$

As objective and results: alcohol level is established, flavor profile of beer is established and carbonation level is established. At the end of fermentation, yeast flocculates and can be easily separated. Cold maturation temperatures will influence beer clarity

\section{Second filtration}

After the completion of fermentation, the beer is filtered in order to remove the yeast and all the other solid derivatives. In this process, auxiliary materials of natural origin are used. After filtration, the clear product is driven to bottling.

\section{Materials}

The Table 2 shows the Reagents, materials and equipment in maize beer production. Figure 1 shows the data for the production of maize beer.

\section{Data}

Step 1: Treatment of maize grains: $n=95 \%$

Maize: 95\%, Impurities: 5\%

Step 2: Germination or malting: $n=30-40 \%$

The treated maize has $10 \%$ water. Water: $126.75 \%$

$$
\left(\mathrm{C}_{6} \mathrm{H}_{10} \mathrm{O}_{5}\right)_{n}+\mathrm{H}_{2} \mathrm{O} \rightarrow n \mathrm{C}_{6} \mathrm{H}_{12} \mathrm{O}_{6}
$$

Step 3: Extraction with water or Mashing: $n=50-60 \%$

Step 4: First Filtration: $n=95 \%$

The percentage of sugar of the wort is about $8.8 \%$.

Step 5: Fermentation: $n=95 \%$

$$
\mathrm{C}_{6} \mathrm{H}_{12} \mathrm{O}_{6} \rightarrow 2 \mathrm{C}_{2} \mathrm{H}_{5} \mathrm{OH}+2 \mathrm{Co}_{2}
$$

Step 6: Second Filtration: $n=98 \%$

Mass of final product: $1000 \mathrm{~kg}$

Water: $89-95 \%$, Dry matter: $5-11 \%$, Ash: 0.27 to $0.47 \%$, Alcohol: 4.3 to $5.8 \%$, Protein: 0.39 to $0.71 \%$

Total sugars: 0.04 to $0.10 \%$

Density relative to water: between 1.00 and 1.02 .

PH: 2.8 to 3.2

Calculation: How many Maize do I need to produce $1000 \mathrm{~kg}$ of beer $5 \%$ alcohol?

Step 2:

$$
\begin{aligned}
& \left(\mathrm{C}_{6} \mathrm{H}_{10} \mathrm{O}_{5}\right)_{n}+n \mathrm{H}_{2} \mathrm{O} \rightarrow n \mathrm{C}_{6} \mathrm{H}_{12} \mathrm{O}_{6} \\
& 162 n(g) 18 n(g) 180 n(g)
\end{aligned}
$$

Step 5:

$$
\begin{aligned}
& \mathrm{C}_{6} \mathrm{H}_{12} \mathrm{O}_{6} \rightarrow 2 \mathrm{C}_{2} \mathrm{H}_{5} \mathrm{OH}+2 \mathrm{Co}_{2} \\
& 180(\mathrm{~g}) \quad 2 \times 46 \mathrm{~g} \quad 2 \times 44 \mathrm{~g}
\end{aligned}
$$

General yield $=0.95 \times 0.40 \times 0.60 \times 0.95 \times 0.95 \times 0.98=0.2017 \quad$ or $20.17 \%$; quantity of ethanol $=1000 \times 5 \%=50 \mathrm{~kg}$

Weight of sugar $($ pure $)=\frac{\text { GEth } \times \text { Msug }}{2 \times \text { Eth } \times \text { Gen.Y }}=\frac{50 \times 162}{2 \times 46 \times 0.2017}=436.5 \mathrm{~kg}$

Technical Weight $=\frac{50 \times 162}{2 \times 46}=88.04 \mathrm{~kg}$

Weight of maize : $100 \mathrm{~kg}$ maize $\rightarrow 72 \mathrm{~kg}$ starch

X $\rightarrow 436.5 \mathrm{~kg}$

$X=\frac{100 \times 436.5}{72}=606.25 \mathrm{~kg}$ of maize

\section{Explanation of steps}

Step 1: Treatment of grains

Quantity of grains: maize $n=95 \%$, impurities $=5 \%$

We need $606.25 \mathrm{~kg}$ of maize $(72 \%$ starch). As maize contains $0.5 \%$ of impurities, so we have $606.25 \mathrm{~kg} \times 100 / 99.5=609.30 \mathrm{~kg}$ as raw material

After treatment (our yield=95\%), we'll get: $606.25 \mathrm{~kg}$ $\mathrm{x} 95 / 100=575.94 \mathrm{~kg}$ as quantity of treated grains.

\begin{tabular}{|l|l|l|l|l|l|}
\hline \multicolumn{2}{|l|}{ Receipts } & \multicolumn{2}{l|}{ Expenditure } \\
\hline $\begin{array}{l}\mathbf{R} \mathbf{a} \mathbf{w} \\
\text { Material }\end{array}$ & $\begin{array}{l}\text { Content } \\
\mathbf{\%}(\mathbf{w})\end{array}$ & Weight Kg & $\begin{array}{l}\text { Products, } \\
\text { Waste }\end{array}$ & Content \%(w) & Weight Kg \\
\hline \multirow{2}{*}{ Maize } & \multirow{2}{*}{99.5} & \multirow{2}{*}{609.3} & Maize & 94.5 & 575.94 \\
\cline { 4 - 6 } & & Dust & 0.05 & 33.36 \\
\hline Total & 609.3 & Total & 609.3 \\
\hline
\end{tabular}

Step 2: Germination 
The yield is $40 \%$. We are $72 \%$ of sugar in $40 \%$ of maize $(0.4 \times 72 / 100=28.8 \%$ of maltose $=575.94 \times 28.8 \%=165.87 \mathrm{~kg})$ and $11.2 \%$ of biomass $(575.94 \times 11.2 \%=64.51 \mathrm{~kg})$. So, the quantity of maltose and biomass is $165.87+64.51=230.38 \mathrm{~kg}$. The quantity of water has been increased in order to do the extraction with water. So, the yield is $230.38 / 575.94=40 \%$.

\begin{tabular}{llllll}
\hline Receipts & \multicolumn{4}{l}{ Expenditure } \\
$\begin{array}{l}\text { R a w } \\
\text { Material }\end{array}$ & $\begin{array}{l}\text { Content } \\
\mathbf{\%}(\mathbf{w})\end{array}$ & $\begin{array}{l}\text { Weight } \\
\mathbf{K g}\end{array}$ & $\begin{array}{l}\text { Products, } \\
\text { Waste }\end{array}$ & $\begin{array}{l}\text { Content } \\
\mathbf{\%}(\mathbf{w})\end{array}$ & $\begin{array}{l}\text { Weight } \\
\mathbf{K g}\end{array}$ \\
\hline Maize & 40 & 575.94 & Maltose & 11.52 & 165.87 \\
& & & Biomass & 4.48 & 64.51 \\
Water & 60 & 863.91 & Water & 84 & 1209.47 \\
& & & & & 1439.85 \\
\hline
\end{tabular}

Step 3: Extraction with water

The yield is $60 \%$. The quantity of mash including sugar is $165.87 \times 60 \%=99.52 \mathrm{~kg}$. The quantity of biomass increases and is 230.38 $99.52=130.86 \mathrm{~kg}$.

\begin{tabular}{llllll}
\hline Receipts & \multicolumn{5}{c}{ Expenditure } \\
\hline Raw material & Content \% (w) & Weight Kg & Products, waste & Content \% (w) & Weight Kg \\
\hline Maltose & 11.52 & 165.87 & Mash including sugar & 6.91 & 99.52 \\
Biomass & 4.48 & 64.51 & Biomass & 9.09 & 130.86 \\
Water & 84 & 1202.9 & Water & 84 & 1202.9 \\
Total & & 1439.85 & Total & & 1439.85 \\
\hline
\end{tabular}

\section{Step 4: First filtration}

The yield is $95 \%$.

The quantity of sugar is $99.52 \times 95 \%=94.54 \mathrm{~kg}$. The percentage of sugar is about $8.8 \%$. So the quantity of wort is $94.54 \times 100 / 8.8=1074.32 \mathrm{~kg}$.

The quantity of precipitate is $1439.85-1074.32=365.53 \mathrm{~kg}$

\begin{tabular}{llllll} 
Receipts & & & Expenditure & \\
Raw material & Content \% (w) & Weight Kg & Products, waste & Content \% (w) & Weight Kg \\
Mash including sugar & 6.91 & 99.52 & Wort(+Sugar) & 74.61 & $1074.32+94.54$ \\
Biomass & 9.09 & 130.86 & & & \\
Water & 84 & 1202.9 & Precipitate & 25.39 & 365.53 \\
Total & & 1439.85 & Total & & 1439.85 \\
\hline
\end{tabular}

\section{Step 5: Fermentation}

The yield is $95 \%$.

The quantity of sugar is $1074.32 \times 95 \%=1020.60 \mathrm{~kg}$. The content of alcohol is about $5 \%$. So the quantity of alcohol is $1020.60 \times 5 \%=51.03 \mathrm{~kg}$. The quantity of lost is $1074.32-1020.60=365.53 \mathrm{~kg}$.

\begin{tabular}{|c|c|c|c|c|c|}
\hline Receipts & & & Expenditure & & \\
\hline Raw Material & $\begin{array}{l}\text { Content \% } \\
\text { (w) }\end{array}$ & Weight Kg & Products, Waste & $\begin{array}{l}\text { Content \% } \\
\text { (w) }\end{array}$ & Weight Kg \\
\hline \multirow[t]{2}{*}{ Wort including sugar } & \multirow[t]{2}{*}{$100,8.8$} & \multirow{2}{*}{$\begin{array}{l}1074.32 \\
94.54\end{array}$} & $\begin{array}{l}\text { Maize beer non-filtrated including } \\
\text { alcohol }\end{array}$ & 95 & $\begin{array}{l}1020.6 \\
51.03\end{array}$ \\
\hline & & & Lost & 5 & 53.72 \\
\hline Total & & 1074.32 & Total & & 1074.32 \\
\hline
\end{tabular}




\section{Step 6: Second filtration}

The yield is $98 \%$.

The quantity of maize is $1020.60 \times 98 \%=1000 \mathrm{~kg}$. The content of alcohol is about $5 \%$. So the quantity of alcohol is $1000 \times 5 \%=50 \mathrm{~kg}$. The quantity of precipitate is $1020.60-1000=20.60 \mathrm{~kg}$

Mass of final product: $1000 \mathrm{~kg}$

Water: $89-95 \%: 890-950 \mathrm{~g}$

Dry matter: 5-11\%, 50-110g,

Ash: 0.27 to $0.47 \%, 2.7$ to $4 . \mathrm{g}$,

Alcohol: 4.3 to $5.8 \%,: 43$ to $58 \mathrm{~g}$,

Protein: 0.39 to $0.71 \%: 3.9$ to $7.1 \mathrm{~g}$

Total sugars: 0.04 to $0.10 \%$ : 0.4 to $1 \mathrm{~g}$

Density relative to water: between 1.00 and 1.02 .

PH: 2.8 to 3.2

\begin{tabular}{llllll} 
Receipts & \multicolumn{5}{c}{ Expenditure } \\
Raw Material & $\begin{array}{l}\text { Content } \\
\mathbf{\%}(\mathbf{w})\end{array}$ & $\begin{array}{l}\text { Weight } \\
\mathbf{K g}\end{array}$ & $\begin{array}{l}\text { Products, } \\
\text { Waste }\end{array}$ & $\begin{array}{l}\text { Content } \\
\mathbf{\%}(\mathbf{w})\end{array}$ & $\begin{array}{l}\text { Weight } \\
\mathbf{K g}\end{array}$ \\
\hline $\begin{array}{l}\text { Maize beer } \\
\text { including } \\
\text { Alcohol.. }\end{array}$ & 99.9 & 1020.6 & $\begin{array}{l}\text { Maize beer } \\
\text { including } \\
\text { Alcohol.. }\end{array}$ & $98,5 \%$ & 1000 \\
$\begin{array}{l}\text { Flavoring } \\
\text { substances }\end{array}$ & 0.1 & 51.031 & Precipitate & 2 & 50 \\
Total & & 1021.60 & Total & 1021.60
\end{tabular}

\section{Practical case for production of $10-15 \mathrm{~kg}$ beer}

Treatment of maize grains: $6 \mathrm{~kg}$ of maize have been treated and used as raw material.

\section{Germination or malting}

Soaking: $6 \mathrm{~kg}$ of treated maize and $9 \mathrm{~kg}$ (9liters) of drinking water have been mixed in a basin $24 \mathrm{~h} / 30^{\circ} \mathrm{C}$.

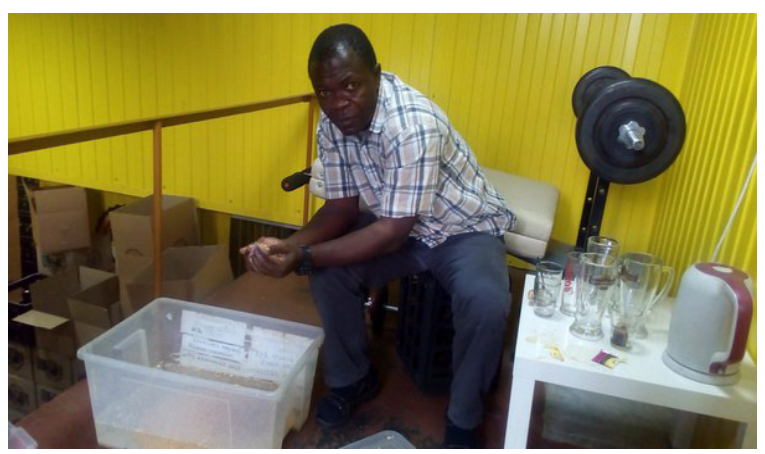

Germination: $5 \mathrm{~kg}$ of water have been removed in a bucket from the soaking. The germination took place on plastic sheet at $30^{\circ} \mathrm{C} / 72 \mathrm{~h}$. The maize was recovered with non toxic vegetable leaves (cleaned before in a bleached solution) in order to retain moisture. The cereals were humidified twice per day. Fermentable sugars resulting from starch hydrolysis can be tested by Trommer's reaction with the formation of $\mathrm{Cu}_{2} \mathrm{O}$ precipitation of red-brown colour.

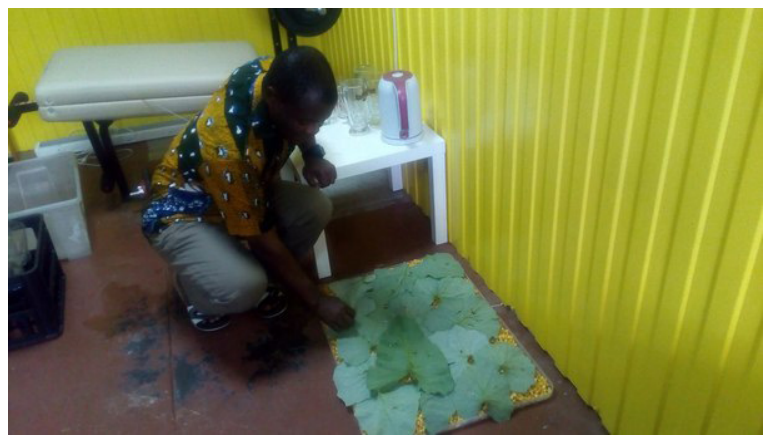

Procedure: $1 \mathrm{~g}$ of dried germinated maize can be poured into a test-tube, 6drops of $10 \% \mathrm{NaOH}$ solution were added and drop by drop, 5 drops of $2 \% \mathrm{CuSO}_{4}$ solution until non-vanishing $\mathrm{Cu}(\mathrm{OH})_{2}$ blue coloration. After heating the content of the test-tube, changing of color can be observed. After heating the blue coloration, if the formation of $\mathrm{Cu}_{2} \mathrm{O}$ precipitation of red-brown color is observed, we are presence of fermentable sugars.

\section{Extraction with water or mashing}

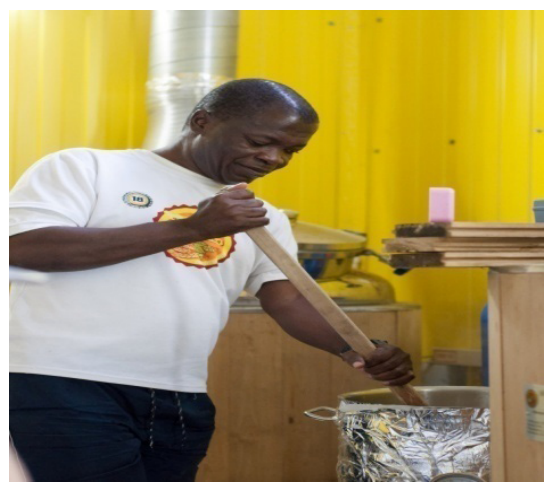

Drying: The product could be dried at $100^{\circ} \mathrm{C} / 4 \mathrm{~h}$ to $5 \mathrm{~h}$ through an oven or in the sun. But, it was dried 3days in the sun through large white sheets of paper. Fortunately we were in summer.

Grinding or pounding: The dried maize has been pounded through a mill. The weight was $6 \mathrm{~kg}$ of malted maize.

Extraction: $6 \mathrm{~kg}$ of malted maize and $1 \mathrm{~kg}$ of rice husks have been added to hot water. 30liters of hot water have been used. First, 15 liters of hot water have been used for the first mashing: $72^{\circ} \mathrm{C} / 90$ minutes. Second, 10liters of the same water have been added for the second mashing: $78^{\circ} \mathrm{C} / 60$ minutes. During the extraction, we were often stirring the mixture. During the filtration, we had added the other 5liters, liter by liter. We had obtained about 20liters of wort with $10^{\circ}$ Brix. If the wort is very starchy after Iodine test, we have to add $1 \mathrm{~kg}$ of barley malt. 
Boiling: The boiling has been done at $100^{\circ} \mathrm{C} / 90$ minutes. About $25 \mathrm{~kg}$ hops have been added after 45 minutes of boiling. We had $15^{\circ}$ Brix.

\section{First filtration}

The wort added with hops had been filtered, and we had obtained about 14 liters of product.

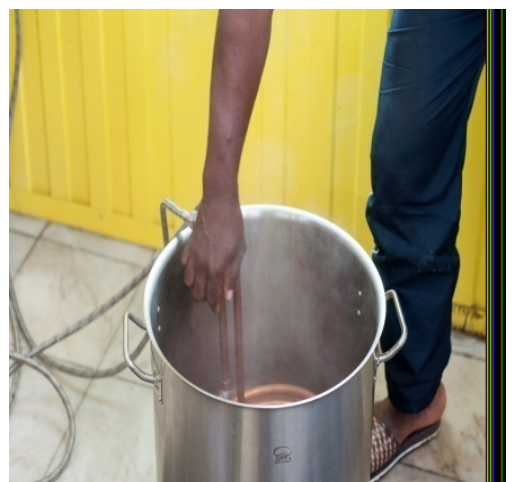

\section{Fermentation}

Cooling: The filtered hopped wort has been cooled between 20 and $25^{\circ} \mathrm{C}$ through heat exchanger.

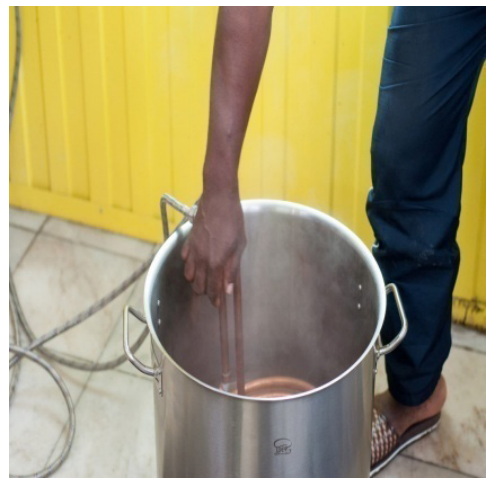

Fermentation: The fermentation has been done with 11 grams of yeast about $24^{\circ} \mathrm{C}$. Before, the tank of fermentation has been rinsed with a paracetic acid solution $1 \%$. We had $15^{\circ}$ Brix (density: 1.06). After one week, we had $11^{\circ}$ Brix (density: 1.045).

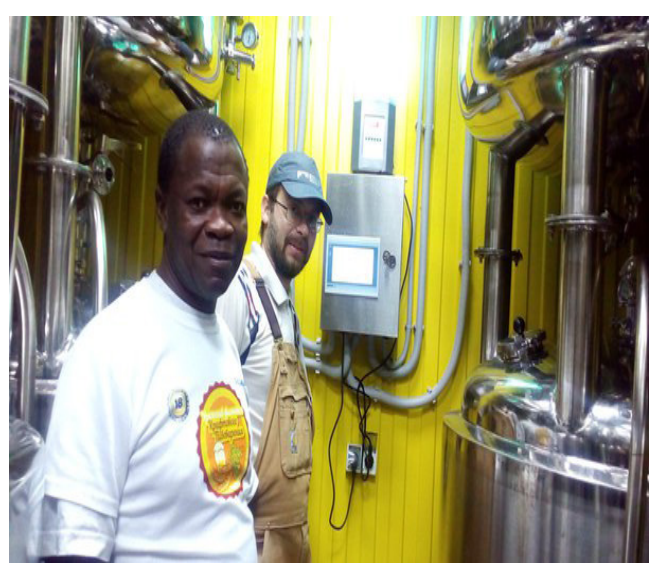

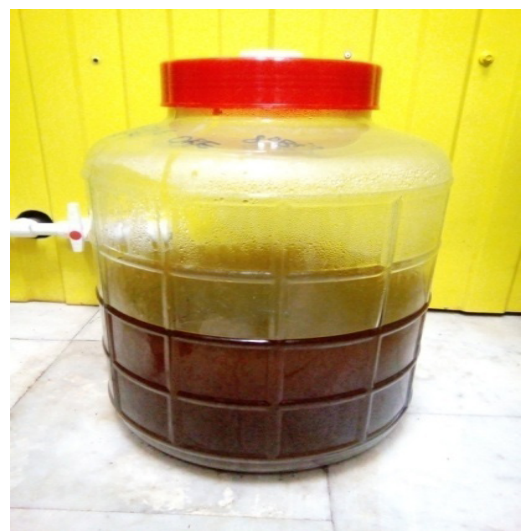

\section{Second filtration}

After two weeks, we had $8^{\circ}$ Brix (density: 1.035).

We have filtered this fermentation pouring the supernatant through a siphon in a tank beforehand cleaned with a paracetic acid solution $(50 \mathrm{ml}$ in about two liters of water).

After Four weeks, we had $8^{\circ}$ Brix (density:1.035). The beverage was filtered in a tank previously washed with $\mathrm{H}_{2} \mathrm{O}_{2}$ solution $1 \%$ for 24 hours and rinsed with the solution of paracetic acid solution.

The tank was tightly closed, then the $\mathrm{CO}_{2}$ to saturation, was injected at $1.7 \mathrm{bars}$.

-The tank was then kept at $4{ }^{\circ} \mathrm{C}$ for one week.

\section{Quality control}

Physical and chemical analysis: Apart from the quality criteria for ashes, and total sugars, our beer meets the physico-chemical criteria of quality (Table 3). Traditional beer usually uses several ingredients and different types of grains and hops. So the quality of ash rise could be improved with time and practice. The quantity of protein is very near to the criteria and good in mashing wort, $0.48 \%$. In any case, too much protein makes the beer cloudy. As for the amount of total sugars, it is high because maize malt does not have all the enzymes alpha and beta amylases in full. There are only beta amylases. However, even if it does not meet the standards, it is not bad sanitary to have a relatively high rate of carbohydrates. Careful analysis could be made to identify exactly all the sugars present.

Sensory analysis: The sensory analysis was carried out on a population of 15 people. The results (A6) and the summary table yielded are the followings (Annexes):

i. Transparency: $2 / 3$, good;

ii. Color: $3 / 3$ excellent;

iii. Flavor: $4 / 4$ excellent;

iv. Taste: $4 / 5$, good

v. Foam and carbon saturation with carbon dioxide:8/10 good.

The sensory analysis was carried out on a population of 15 people about transparency, color, flavor, taste and foam. They all appreciated 
our corn beer, except for the criterion of the foam which was not very strong at the opening. The results are mentioned in the above Table 4.

With the mark of $21 / 25$, our maize beer was good. All the 15 people appreciated our corn beer. However, they found that the foam which was not very strong at the opening. The results are mentioned in the table above. Two of them even ordered a dozen bottles of 2liters of our beer. Unfortunately, the quantity was insufficient during the festival. The quality control about the sensory analysis, meets the criteria. However, much remains to be done to perfect our product. That is why we want to compare the chemical characteristics with those of traditional beer, to check whether it is close to international standards and whether it can have the same therapeutic qualities as traditional beer.

\section{Microbiological analysis}

The microbiological analysis was not carried out for the following reasons. All arrangements (food hygiene, boiling, adding $\mathrm{CO}_{2}$ in final product, etc.) have been made to avoid contamination of the product by the application of the HACCP system. So, all dangers of physical, chemical and biological origin have been minimized to the maximum. At all stages of production from raw materials until the final product, we have endeavored to apply and respect the rules of personal hygiene, clothing, environment, premises, equipment, etc.

On the other hand, if the microbiological analysis should be done, we should research the following germs: Lactobacillus, Pediococcus, Acetobacter, Zymomonas mobilis, etc. ${ }^{14-24}$ Which are not dangerous but contaminate the beer and can affect its taste and smell. But fortunately all necessary measures have been taken. Moreover, the $\mathrm{pH}$, which is 4.7 , is not conducive to the development of certain pathogenic microorganisms such as Enterobacteria.

There are also yeasts which are defenders of our beer against other possible microorganisms of contamination. Finally, there is bitterness (10.8IBUs) which prevents dangerous microorganisms from developing there. However, microbiological analysis could have been carried out as a precautionary measure and verified the effectiveness of the prevention measures. We wanted to spare our department from expenses. Food hygiene is also economy.

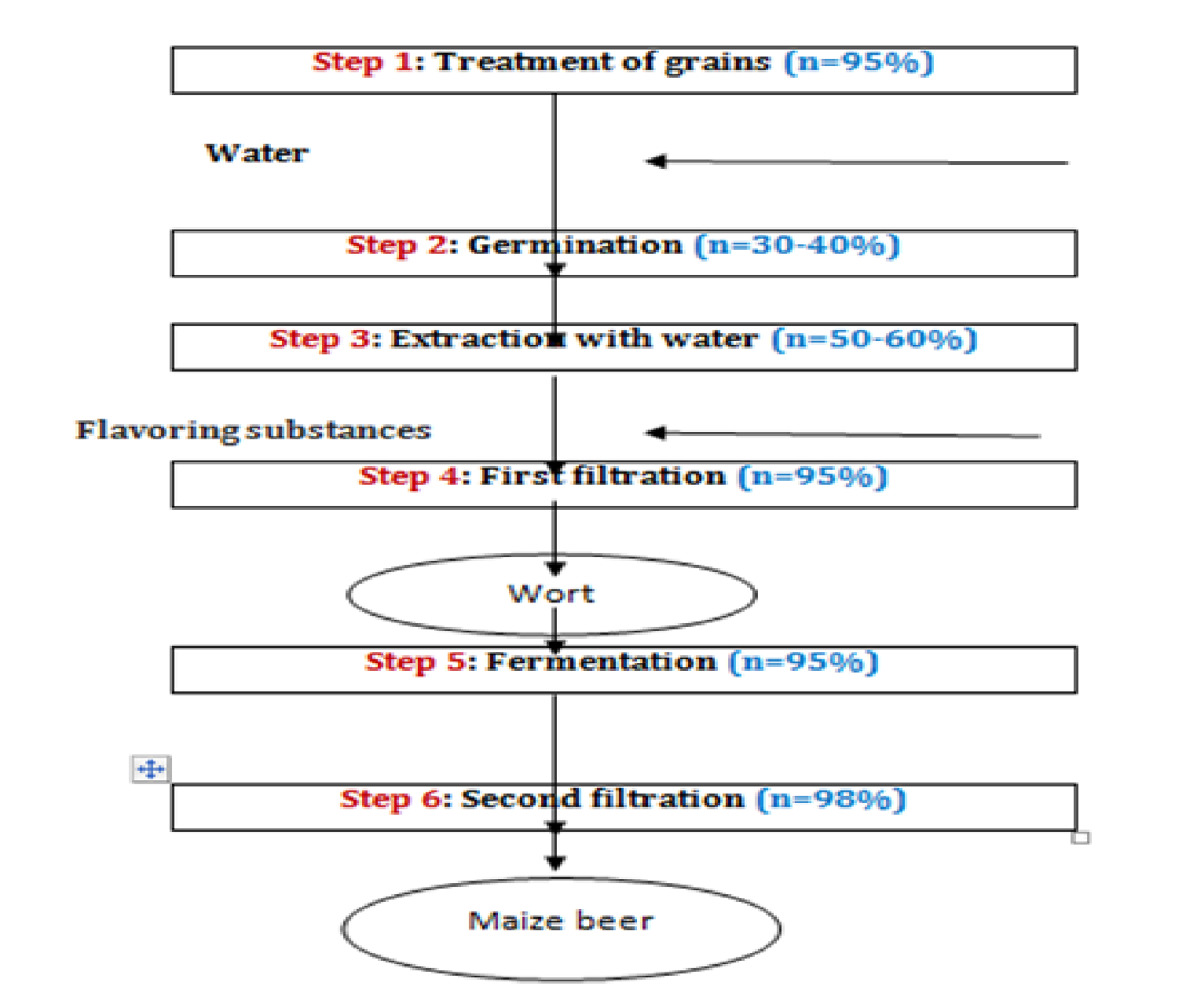

Figure I Principles of the production of maize beer. 
Table I Comparative chemical composition of barley and maize

\begin{tabular}{|c|c|}
\hline Raw barley & Maizegrain \\
\hline \multicolumn{2}{|l|}{ Nutritional value per $100 \mathrm{~g}$} \\
\hline Energy 1,473 kJ (352 kcal) & Energy 1,528 kJ (365 kcal) \\
\hline \multicolumn{2}{|l|}{ Carbohydrates } \\
\hline $77.7 \mathrm{~g}$ & $74 \mathrm{~g}(\mathrm{starch}=72-73 \%)$ \\
\hline Sugars $0.8 \mathrm{~g}$ & Sugars $0.64 \mathrm{~g}$ \\
\hline Dietary fiber $15.6 \mathrm{~g}$ & Dietary fiber $7.3 \mathrm{~g}$ \\
\hline Fats $1.2 \mathrm{~g}$ & Fats $4.74 \mathrm{~g}$ \\
\hline Proteins $9.9 \mathrm{~g}$ & Proteins 9.4g \\
\hline \multicolumn{2}{|l|}{ Vitamins } \\
\hline Beta carotene $13 \mu \mathrm{g}$ & Beta carotene $97 \mu \mathrm{g}$ \\
\hline Lutein zeaxanthin $160 \mu \mathrm{g}$ & Lutein zeaxanthin $1355 \mu \mathrm{g}$ \\
\hline Thiamine (B1) $0.191 \mathrm{mg}$ & Thiamine (B1) $0.39 \mathrm{mg}$ \\
\hline Riboflavin (B2) $0.114 \mathrm{mg}$ & Riboflavin (B2) $0.20 \mathrm{mg}$ \\
\hline Niacin (B3) 4.604mg & Niacin (B3) $3.63 \mathrm{mg}$ \\
\hline Pantothenic acid (B5) $0.282 \mathrm{mg}$ & Pantothenic acid (B5) $0.42 \mathrm{mg}$ \\
\hline Vitamin B6 0.26mg & Vitamin B6 0.62mg \\
\hline Folate (B9) $23 \mu \mathrm{g}$ & Folate (B9) $19 \mu \mathrm{g}$ \\
\hline Choline $37.8 \mathrm{mg}$ & Vitamin E $0.49 \mu \mathrm{g}$ \\
\hline Vitamin K $2.2 \mu \mathrm{g}$ & Vitamin K $0.3 \mu \mathrm{g}$ \\
\hline \multicolumn{2}{|l|}{ Minerals } \\
\hline Calcium 29mg & Calcium $7 \mathrm{mg}$ \\
\hline Iron $2.5 \mathrm{mg}$ & Iron $2.71 \mathrm{mg}$ \\
\hline Magnesium 79mg & Magnesium 127mg \\
\hline Manganese $1.322 \mathrm{mg}$ & Manganese $0.49 \mathrm{mg}$ \\
\hline Phosphorus $221 \mathrm{mg}$ & Phosphorus 210mg \\
\hline Potassium 280mg & Potassium $287 \mathrm{mg}$ \\
\hline Sodium 9mg & Sodium $35 \mathrm{mg}$ \\
\hline Zinc $2.13 \mathrm{mg}$ & Zinc $2.21 \mathrm{mg}$ \\
\hline
\end{tabular}

Table 2 Reagents, materials and equipment in maize beer production

\begin{tabular}{llll}
\hline Objects & Reagents & Materials & Equipment \\
\hline Maize (Drygrains) & Bleach solution & Basin & Weighs \\
\hline Drinking water & Solution of $\mathrm{NaOH} 10 \%$ & Material to winnow & Test tubes \\
Rice husks & Solution of $\mathrm{CuSO}_{4} 2 \%$ & Bowl of a liter & Thermometers \\
Barley (optional) & Paracetic acid solution & Gloves & Refractometer \\
Hops Dr. Rudy & Iodine solution & Filter or piece of clean cloth & Oven \\
Abbaye Belgium Ale Yeast & $\mathrm{H} 2 \mathrm{O} 2$ solution $1 \%$ & Cassava leaves or other non toxic vegetable leaves & Mill or mortar and pestle \\
& & Plastic sheet & Crutcher \\
& & Bucket & Cooler \\
\hline
\end{tabular}


Table3 Physical and chemical analysis of maize beer

\begin{tabular}{lll}
\hline Tests & Criteria & Results \\
\hline Water & $89-95 \%$ & $89.90 \%$ \\
Dry matter & $5-11 \%$, & $5.40 \%$ \\
Ash & 0.27 to $0.47 \%$ & $0.07 \%$ \\
Alcohol & 4.3 to $5.8 \%$ & $4.70 \%$ \\
Protein & 0.39 to $0.71 \%$ & $0.34 \%$ \\
Total sugars & 0.04 to $0.10 \%$ & $4.50 \%$ \\
Density relative to water & 1.00 and 1.02 & 1.02 \\
pH & 2.8 to 6.2 & 4.7 \\
\hline
\end{tabular}

Table 4 Overall maize beer quality assessment in scores

\begin{tabular}{lll}
\hline Assessment & Total score & Our score \\
\hline Excellent & $22 \ldots 25$ & \\
Good & $19 \ldots 21$ & \\
Satisfactory & $13 \ldots 18$ & 21 \\
Poor & $<12$ & \\
\hline
\end{tabular}

\section{Conclusion}

Throughout sub-Saharan Africa, maize is the grain of choice to produce traditional cloudy and opaque (maize) beers. The key ingredient of these beers is maize malt, which provides hydrolytic enzymes (especially amylases to ferment sugars into ethanol and carbon dioxide), starch (the source of fermentable sugars), yeast nutrients and beer flavour and colour substances.

The design and production of maize beer can be beneficial for everyone in tropical African countries, for the following reasons:

i. The main raw material is on site and cheaper, otherwise farmers will be encouraged to produce more in the fight against poverty.

ii. Maize beer can be produced by craftsmen.

iii. It may have to increase economic activities and employment creation, etc. It is possible to do the comparison of the all physical and chemical characteristics between barley beer and maize beer in order to check the components which are responsible for health benefits in maize beer like barley beer.

The problem of lack of $\beta$-amylase in maize can be solved by importing barley malt from temperate countries in reduced amount $(10 \%$ in the manufacture of beer maize) or associating maize with other cereals. Our work can be improved in order to preserve the shelf life, organoleptic and chemical qualities of our maize beer and also to avoid chemical, physical and microbial contamination. A whole special attention must be made to all unit operations such as germination, drying, mashing, boiling, fermentation, etc. so that our production process could exceeds African borders. By the way, we have to conduct a study about further research of maize beer and barley beer comparison and what would be the mixing percentage of both for healthy person and what preservatives are required.

\section{Acknowledgements}

i. All our teachers for their very important, rich, efficient and concrete lectures, specially :

ii. Professor Maxim Mironov (our Supervisor) and Professor Elena Kovaleva for their efforts in order to succeed our Food biotechnology program;

iii. Mr. Alexey Shootov : General Director of Beersfan;

iv. Mr. Vladimir Pochivalov: Director;

v. Mr. Vladislav Ivoilov: Manager;

vi. Mr. Dmitriy Kopotilov: Brewer;

vii. Mr. Alexander Baracuda: Brewer;

viii. Miss Yulia Simanova: our translator from Russian into English and vice versa.

\section{Conflict of interest}

The author declares no conflict of interest.

\section{References}

1. Akimbekov Nuraly. Biotechnological processing of plants materials, Master of Food biotechnology. Russia: UrFU Yekaterinburg; 2016.

2. Brewers Association of Canada. Health effects of moderate beer consumption. 2009. p. 1-28.

3. Confédération des brasseurs du marche commun, caracteristiques nutritives de la bière ; 1999.

4. FAO. Maize in human nutrition. Food and agriculture organization of the united nations; 1992.

5. François Lyumugabe, Jacques Gros, John Nzungize, et al. Characteristics of African traditional beers brewed with sorghum malt: a review. Base [En ligne] numéro. 2012;16(4):509-530.

6. Kovaleva EG. Beer and low alcoholic beverage processing course, Master of Food biotechnology. Russia: Ur FU Yekaterinburg; 2016.

7. Leitao C. PhD Thesis, Study of compounds with a technological and functional interest in the beer. 2016;8:154.

8. Maxim Mironov. Mass and energy balance in biotechnology, Master of Food biotechnology. Russia: UrFU, Yekaterinburg; 2016.

9. Perry Robert H, Chilton Cecil H, Kirkpatrick Sidney D. Chemical Engineers' Handbook. 4th ed. India: Mc Graw-Hill;1963. p 4-21.

10. Pisoschi AM, Negulescu GP. Methods for total antioxidant activity determination: a review. Biochem \& Anal Biochem. 2011;1:106.

11. Shyam Verma, Jvo Siegrist, Jennifer Claus, et al. Microbial Quality Control of Beer. Sigma Aldrich; 2013. p. 1-12.

12. Pai TV, Sawant SY, Ghatak AA, et al. Characterization of Indian beers: chemical composition and antioxidant potential. J Food Sci Technol. 2015;52(3):1414-1423.

13. University of Maryland Medical Center (UMMC); 2018.

14. Wahauwouélé Hermann Coulibaly, Kouadio Florent N'guessan, Ibourahema Coulibaly, et al. Les levures et les bactéries lactiques impliquées dans les bières traditionnelles à base de sorgho produites 
en Afrique subsaharienne (synthèse bibliographique). Base [En ligne] 2014;18(2):209-219.

15. A $16^{\text {th }}$ century Brewing.

16. Les glucides fournissent l'essentiel de lénergie dont nous avons besoin. Tous les glucides, au cours de la digestion, sont dégradés plus ou moins vite en une molécule de glucose, le plus simple de tous les glucides.

17. Équipement de chromatographie en phase gazeuse avec passeur déchantillons robotize.

18. Unités du SI et CNTP, sauf indication contraire.
19. N-Butanol Wikipedia.

20. A modern self-contained HPLC

21. Bitterness of beer

22. Smith B. Beer Color: Understanding SRM. Lovibond and EBC; 2008.

23. A hydrometer floating in a test jar of wort. The specific gravity reading is approximately 1.050 .

24. Analyses microbiologiques sur bières. 